\title{
Drama: A Neglected Source in Language Teaching to Improve Communication
}

\author{
Mustafa Altun ${ }^{1}$ \\ ${ }^{1}$ English Language Teaching Department, Ishik University, Erbil, Iraq \\ Correspondence: Mustafa Altun, Ishik University, Erbil, Iraq. E-mail: mustafa.altun@ishik.edu.iq
}

Received: May 9, 2019 Accepted: June 13, 2019 Online Published: August 26, 2019

doi:10.5539/ijel.v9n5p242 URL: https://doi.org/10.5539/ijel.v9n5p242

\begin{abstract}
Although drama takes several forms such as role-playing, story-telling, dialogues, etc., it is majorly used for the purpose of communication. Drama is an influential language tool to prepare learners how to function appropriately in real life situations. A language learning environment in which dramatic activities are employed to practice the language helps learners produce discourse in realistic conversations. The present paper shows the benefits of drama in language learning. In particular, the paper aims to reveal the contributions of engaging in conversation contents through role-play and simulation activities to the development of communication skills. The great difference between the pre survey and post survey questionnaires indicated that the students demonstrated a move towards the inclusion of drama in language learning and oral skills development.
\end{abstract}

Keywords: drama, role-playing, simulation, language learning, communication skills

\section{Introduction}

Literature has been integrated into language curriculum since the early 20th century (Knutson, 1997). The use of literature was considered worthy of concern when the Grammar-Translation Method enjoyed its popularity in language instruction (Mart, 2013). Literature was the major teaching tool then in the language classroom to master vocabulary and grammatical structures (Hadaway, Vardell, \& Young, 2002; Mart, 2018a; Duff \& Maley, 1990). However, in the 1960s and 1970s the Grammar Translation Method was viewed as unprestigious in language learning; thus, literature was excluded from language curriculum. In particular with the onset of communicative language teaching, the use of literature in language learning was downgraded and the emphasis was placed on the development of language skills (Mart, 2018a). It goes without saying that the attainment of communicative competence relies on the use of language skills competently (Mart, 2018b). However, the inclusion of literature in language teaching in the 1970s resulted rather insufficient since it had little functional application. Literature once again in the late 1970s and 1980s came into prominence and played a preeminent role at all levels of language learning (Paesani, 2011; Mart, 2018c). After a long contentious debate, literature today is welcome at all levels in the language classroom because it has been found conducive to language learning.

The underlying idea in language learning is that compared with simplified texts the use of authentic texts is more useful because the language used in them is natural; therefore, they enable learners to notice various aspects of the target language (Mart, 2017). Literary texts are authentic materials and they have the potential to increase language awareness. Learners make huge leaps in language learning when they are engaged in real examples provided by authentic materials to create meaning (Kramsch, 1994). The use of literary texts is suitable in the language classroom because of the fact that they are rich in language input and they can enrich vocabulary, promote reading proficiency, develop language acquisition and enhance language skills (Liaw, 2001; McKay, 1982).

Drama, one of the literary genres, is defined as "a wide range of oral activities that have an element of creativity present" (Hubbard et al., 1986, p. 317). It is simply perceived as the body of written plays (Elam, 1980) and since 1950s its teaching has been embraced in language teaching (Zafeiriadou, 2009). Drama has become an aid in language education for the development of communicative competence. Drama creates a learning environment for learners in which they can experience the natural use of language (Davies, 1990). By means of dramatic activities language learners have an opportunity to engage in authentic language and practice grammatical and lexical items in a context. In addition, drama activities encourage learners to use the language 
more confidently because such practice opportunities as rehearsals and performances help learners nourish their self-esteem. This paper focuses on the use of dramatic activities in the language classroom and their possible contributions to the development of language acquisition and communication skills. At the same time, the present paper suggests some strategies how drama activities should be integrated into language learning.

\section{Literature Review}

\subsection{Integrating Drama into Language Learning}

Drama can be introduced into language classroom at all ages and levels as long as the learners are well-prepared (Davies, 1990). The use of drama activities has been essential in the language learning process because all learners who are confident in their work can profit from involvement in drama. Drama in the language classroom cannot be neglected due to its role in presenting models of conversational interactions (Boria, 2003). Language learners can eradicate their fear of communication in public when they have practice opportunities in the form of rehearsal. Via (1972) pointed out that performances and rehearsals help learners have an improved sense of confidence. That leaners experience learning through acting fosters grasp of language.

Cunico (2005) argues that drama is introduced into the foreign language classroom in six different ways; first, a play can be used in the target language with the participation of learners in the classroom. Second, drama techniques can be applied to English teaching to enable learners to learn by acting. Doing together while acting a play triggers interest of learners in language learning and creates a climate of trust in the classroom. Third, drama can be used to explore cultural issues for cultural development of learners. Fourth, drama can be introduced to practice the language through language-based activities because it is modeled on real-life conversations. Fifth, stylistic approach can be adopted to foster systematic awareness of the linguistic system and finally, 'global simulation' approach which was developed by Care and Debyster (1984) can be implemented to create communicative situations. Learners by means of engaging activities and discussions on characters, setting and plot promote their language learning.

Drama activities can be effective if they are presented in four stages to learners in the language classroom (Davies, 1990); in the presentation stage, a new language item is introduced to learners in the form of drama. In the practice stage, grammatical structures and new vocabulary are practiced through using exercises. In the further practice stage, learners are given an opportunity to practice the newly learnt language items in a new context. Completing gaps and dialogues offers learners the possibility of using the language for communication. Finally, in the free stage learners' experiment with the target language by means of role-play activities, act out a scenario and discussions. The use of role-play in an EFL classroom is one of the easiest ways to enhance communication skills of learners. Dorathy and Mahalakshmi (2011) state that "role play is very important in teaching English because it gives students an opportunity to practice communicating in different social contexts and in different social roles. In addition, it also allows students to be creative and to put themselves in another person's place for a while" (p. 2). Altun (2015) argues that learners need to experience a real language environment for the development of language skills and role play activities have the potential to foster their communication skills by means of engaging them in some routine phrases and common words.

Similarly, Holden (1982) suggests five stages to integrate drama activities into language teaching. In the first stage the theme or idea is introduced to learners and clear instructions are provided to ensure that they know what to do. In the second stage, learners in groups discuss about the possible steps concerning how they will do it. In the third stage, learners in the same group articulate their interpretations to decode upon the most suitable idea. In the fourth stage, learners verbalize their ideas to each other and finally in the fifth stage learners discuss their solutions in groups.

\subsection{Why Drama Is Essential in Language Learning}

The need for drama is increasingly important for learners who have fewer opportunities to use the language in everyday life. Foreign language learning requires learners to expose to the target language on a regular basis. Drama reflects real life situations; for that reason, when learners practice the language in a particular situation of a play, they experience how language is used in real-world contexts. Learning environments in which learners practice the language in authentic situations enable them to develop their language skills. The practice of a play requires learners to listen to their teachers or friends and react to what they say. This interaction involves learners in communication activities thus enhances their speaking skills. In other words, learners can benefit from drama to bridge the gap between listening and speaking. Similarly, learners notice how language structures are created during a drama activity. This practice helps them to enhance their writing skills. Learner involvement in language practice allows them to be active participants. As a result, when learners become interested in language learning, they stand a better chance of promoting their language proficiency. Also, language skills are integrated 
naturally in drama (Maley \& Duff, 2005). This advantage allows learners to see how language works in a meaningful language learning setting. It should be borne in mind that self-confidence plays a key role in language development. Drama provides an opportunity to learn by doing that boosts learners' confidence and encourage them for better achievement in language learning. Fuentes (2010) argues that self-confidence enhances motivation which is a need for learners for language proficiency development. A stressful learning environment may negatively affect learning; however, drama creates an enjoyable learning setting in which learners eagerly perform activities in the classroom.

\section{Research Questions}

1) Does the use of drama in the foreign language classroom promote their language learning?

2) Does the inclusion of drama in the language classroom develop communication skills?

\section{The Research Context}

The present study was conducted in an English Language Teaching program at a university. All third-year students whose native languages are not English took part in the study. These 40 students ( 25 females; 15 males) met three hours in a week for drama classes. A pre-survey questionnaire was carried out at the beginning of the semester in their regular drama classes. The same 4-point Likert-scaled questionnaire was applied at the end of the semester to reveal the views of the students about the influence of dramatic activities on language learning and oral skills development. The curriculum of the program includes drama teaching only in the third year. For that reason, the students did not experience dramatic experiences until their third year in the program. After the pre survey questionnaire, the students in their drama classes were engaged in reading activities, seeking answers for character, setting and action questions, analyzing theme and style and taking part in discussions in which they could articulate their opinions. Additionally, role-play activities and simulations were used to provide an opportunity for the students to engage in real-life situations and encourage them to practice the language.

\section{Findings and Discussion}

Table 1. The results of pre and post surveys

\begin{tabular}{|c|c|c|c|c|c|c|c|c|c|c|}
\hline & \multicolumn{5}{|c|}{ Pre-survey } & \multicolumn{5}{|c|}{ Post-survey } \\
\hline & \multicolumn{5}{|c|}{ Agree/disagree with each statement } & \multicolumn{5}{|c|}{ Agree/disagree with each statement } \\
\hline & $\mathrm{N}$ & Mean & SD & $\mathrm{D}$ & A & $\mathrm{N}$ & Mean & SD & $\mathrm{D}$ & A \\
\hline 1. Literature is conducive to language learning & 40 & 1.52 & .850 & 31 & 9 & 40 & 3.56 & .874 & 7 & 33 \\
\hline $\begin{array}{l}\text { 2. Drama, one of the literary genres, can be used in } \\
\text { language teaching }\end{array}$ & 40 & 1.46 & .876 & 30 & 10 & 40 & 3.54 & .796 & 8 & 32 \\
\hline $\begin{array}{l}\text { 3. Drama helps learners experience the natural use } \\
\text { of language }\end{array}$ & 40 & 1.65 & .796 & 29 & 11 & 40 & 3.78 & .920 & 6 & 34 \\
\hline $\begin{array}{l}\text { 4. Dramatic activities help learners practice } \\
\text { grammatical items in context }\end{array}$ & 40 & 1.19 & .783 & 32 & 8 & 40 & 3.32 & .769 & 11 & 29 \\
\hline $\begin{array}{l}\text { 5. Dramatic activities help learners' practice lexical } \\
\text { items in context }\end{array}$ & 40 & 1.74 & .841 & 28 & 12 & 40 & 3.48 & .852 & 10 & 30 \\
\hline $\begin{array}{l}\text { 6. Dramatic activities help learners nourish } \\
\text { self-esteem }\end{array}$ & 40 & 1.10 & .910 & 33 & 7 & 40 & 3.61 & .890 & 8 & 32 \\
\hline $\begin{array}{l}\text { 7. Dramatic activities offer pedagogical advantages } \\
\text { to pay attention to conversational details }\end{array}$ & 40 & 1.58 & .845 & 31 & 9 & 40 & 3.57 & .866 & 9 & 31 \\
\hline $\begin{array}{l}\text { 8. Drama is considered as a motivational material } \\
\text { for the acquisition of meaningful interaction }\end{array}$ & 40 & 1.26 & .839 & 32 & 8 & 40 & 3.60 & .887 & 8 & 32 \\
\hline $\begin{array}{l}\text { 9. Drama helps with the development of oral } \\
\text { communication }\end{array}$ & 40 & 1.34 & .884 & 31 & 9 & 40 & 3.79 & .916 & 6 & 34 \\
\hline
\end{tabular}

Note. SD: Standard Deviation, D: Disagree, A: Agree.

Table 1 demonstrates that the responses of the students to the statements changed to a large extent after the study. We see that a considerable number of responses showed agreement in the post survey. The results indicate that the inclusion of literature in language learning received little attention in the pre survey; however, there is a move towards the use of literature in the language classroom in the pre survey. While only 9 students agreed about this statement in the pre survey, 33 students agreed with the same statement at the end. Similarly, the responses of the students are positively high in the post survey concerning the use of drama in language teaching. Only 11 students agreed about the role of drama in experiencing the natural use of language at the beginning but 
this number rose to 34 in the post survey. As regards the contributions of drama to practicing grammatical and lexical units in context, a large majority of the students reported agreement in the post survey questionnaire. A moderately high number of responses showed agreement towards the benefits of drama in nourishing self-esteem. It is noteworthy that there is a great positive shift towards the use of dramatic activities in developing communication skills. The table clearly shows that a large number of the students reported agreement about the pedagogical advantages of dramatic activities to pay attention to conversational details, create a meaningful interaction and develop oral communication.

Table 2. Comparison of pre and post surveys

\begin{tabular}{|c|c|c|c|c|}
\hline Pairs & Statements & $\mathrm{t}$ & $\mathrm{df}$ & P-Value \\
\hline Pair 1 & Pre-Survey 1 & -7.197 & 39 & $.000 *$ \\
\hline & Post Survey 1 & & & \\
\hline Pair 2 & Pre-Survey 2 & -8.324 & 39 & $.000 *$ \\
\hline & Post Survey 2 & & & \\
\hline Pair 3 & Pre-Survey 3 & -7.356 & 39 & $.000^{*}$ \\
\hline & Post Survey 3 & & & \\
\hline Pair 4 & Pre-Survey 4 & -8.165 & 39 & $.000^{*}$ \\
\hline & Post Survey 4 & & & \\
\hline Pair 5 & Pre-Survey 5 & -9.122 & 39 & $.000^{*}$ \\
\hline & Post Survey 5 & & & \\
\hline Pair 6 & Pre-Survey 6 & -8.384 & 39 & $.000^{*}$ \\
\hline & Post Survey 6 & & & \\
\hline Pair 7 & Pre-Survey 7 & -9.235 & 39 & $.000 *$ \\
\hline & Post Survey 7 & & & \\
\hline Pair 8 & Pre-Survey 8 & -8.622 & 39 & $.000^{*}$ \\
\hline & Post Survey 8 & & & \\
\hline Pair 9 & Pre-Survey 9 & -7.864 & 39 & $.000 *$ \\
\hline & Post Survey 9 & & & \\
\hline
\end{tabular}

A paired sample t-test shows that the difference between pre and post survey questionnaires is statistically significant. All p-values are less than .05 which means that all pairs show statistically significant results. The analysis shows that there was an increased attention towards the use of drama in language learning; in particular, for the development of communications skills.

The recent swing from linguistic competence to communicative competence has placed an emphasis on speech-enriched language curriculum. Although, foreign language learners may show certain difficulties during communication, Ur (1996) stresses that "of all the four skills (listening, speaking, reading and writing), speaking seems intuitively the most important" (p. 20). Davies and Pearse (2000) take the discussion further and state (2000) that "real success in English teaching and learning is when the learners can actually communicate in English inside and outside the classroom". In addition to practice communicating successfully demands knowledge about linguistic elements.

The use of literature by means of classroom discussions has proved useful in developing speaking skills (Mart, 2019). Similarly, the use of drama activities can impact the development of oral communication. In a study conducted by Park and Won (2003) it was found that drama helped language learners with the improvement of communicative competence. In particular, the study carried out by them showed that learners developed their grammar and vocabulary knowledge through drama which is considered as essential items in the development of communication skills. Similarly, Fuentes (2010) argues that drama has some linguistic advantages such as vocabulary learning and fluency. Teaching drama is an active approach and it requires language learners to listen, act and speak. Learners need to cooperate and communicate with each other. A speech-enriched curriculum can be developed through learner involvement in drama activities. Mart (2012) argues that for the development of spoken English the best reading materials are dramas, plays and dialogues because they involve sentences and phrases used in daily conversations. Dramatic activities can be employed in the language classroom in various ways such as dialogues, role-play, simulation, and dramatic story telling. The present study mainly focused on role-play and simulation activities.

Role-play activities "are usually short, spontaneous presentations" (Bonwell \& Eison, 1991, p. 47) but gives 
language learners the opportunity to engage in real-life situations. The primary goal of role-play is to encourage interaction and practice the language in the real world to prepare them for the situations they can meet outside the classroom. Role-playing language activities are useful in the language classroom in that they engage learners in real-world scenarios which enable them to learn skills such as cooperation, debate and teamwork. The application of these skills in real life situations motivates learners to use the language for real purposes.

Simulation activities also boost interaction and allow learners how to function appropriately in a social situation (Davies, 1990). Simulations are defined as "simplified patterns of human interactions or social processes where the players participate in roles" (Davison \& Gordon, 1978, p. 55). Simulation and role-play activities cannot be clearly distinguished; however, simulations are more structured and require learners to have background information to work. The accomplishment of tasks in simulations should be done within a defined setting and time limit.

The creation of an effective learning environment holds an important place in language teaching in order to develop practice competence. Norton (2010) to support his argument of creating an ideal learning setting attests that "language teaching is most effective when the teacher recognizes the multiple identities of students in the class, and develops pedagogical practices that enhance students' investment in the language practices of the classroom" (p. 179). Role-playing and simulations are teaching aids which are commonly used in the language classroom. These teaching tools have clear advantages to enable learners use their linguistic competence in appropriate language situations. When language learners engage in conversation contents by means of role-play and simulation activities, they stand a better chance of producing grammatical regular discourse in realistic conversations.

While dialogues in textbooks are used to introduce vocabulary and grammatical forms, dramatic dialogues are linked with everyday conversation and offer pedagogical advantages to pay attention to conversational details. It is worth considering that, learners are exposed to theoretical and practical aspects of the language when drama is incorporated in language teaching (Whiteson, 1996). Drama is considered as a motivational material for the acquisition of meaningful interaction. There is no blinking the fact that drama activities bridge the gap between classroom and real-life situations (Davies, 1990). Drama is seen as a tool to introduce natural usage of language that learners process in course-book dialogues. Therefore, it makes sense that language learners foster speaking skills from involvement in drama activities.

\section{Conclusion}

When language learners are immersed in practices in the classroom learning is facilitated because learn by doing experience can provide them the required skills and elements they need for language development. Drama can be introduced to make huge leaps in language proficiency development. Drama has the potential to achieve the desired outcomes in the development of communication skills. Drama is based on real-life conversations; for that reason, it gives learners an opportunity to practice the language for real purposes. In other words, dramatic activities help learners familiarize themselves with conversations used in real life. Role-play and simulation activities are commonly used dramatic exercises which are designed to prepare learners how to use linguistic elements in appropriate language situations. Dramatic activities encourage learners in realistic conversations which help learners produce discourse in real-life situations. With this in mind, drama is an influential tool in the language classroom to promote communication skills.

\section{References}

Altun, M. (2015). Using Role-Play Activities to Develop Speaking Skills: A Case Study in the Language Classroom. International Journal of Social Sciences \& Educational Studies, 1(4), 27-33.

Bonwell, C. C., \& Eison, J. A. (1991). Active learning: Creating excitement in the classroom. Washington, D.C.: The George Washington University.

Boria, M. (2003). Teaching language through literature. Tuttitalia, 27, 3-13.

Care, J. M., \& Debyser, F. (1984). Simulations globales. CIEP/BELC.

Cunico, S. (2007). Teaching language and intercultural competence through drama: Some suggestions for a neglected resource. The Language Learning Journal, 31(1), 21-29. https://doi.org/10.1080/09571730585200051

Davies, P. (1990). The use of drama in language teaching. TESL Canada Journal, 8(1), 87-99. https://doi.org/10.18806/tesl.v8i1.581

Davies, P., \& Pearse, E. (2002). Success in English teaching. Shanghai: Shanghai Foreign Language Education 
Press.

Davison, A., \& Gordon, P. (1978). Games and simulations in action. London: Woburn Press.

Dorathy, A. A., \& Mahalakshmi, S. N. (2011). Second language acquisition through task-based approach Role-play in English language teaching. English for Specific Purposes World, 33(1), 1-7.

Duff, A., \& Maley, A. (1990). Literature. Oxford: Oxford University Press.

Elam, K. (1980). The semiotics of theatre and drama. London: Methuen. Reprinted in 1988 by Routledge.

Fuentes, A. (2010). Break a leg! The use of drama in the teaching of English to young learners. A case study. Retrieved April 15, 2019 from http:/www.spertus.es/Publications/Araceli/29-AESLA_2010.pdf

Hadaway, N., Vardell, S., \& Young, T. (2002). Literature-based instruction with English language learners, K-12. Boston: MA: Allyn and Bacon.

Holden, S. (1982). Drama in language teaching. Longman.

Hubbard, P., Jones, H., Thornton, B., \& Wheeler, R. (1986). A training course for TEFL. Oxford: Oxford University Press.

Knutson, E. (1997). Reading with a purpose: Communicative reading tasks for the foreign language classroom. Foreign Language Annals, 30(1), 49-57. https://doi.org/10.1111/j.1944-9720.1997.tb01316.x

Kramsch, C. (1994). Context and culture in language teaching. Hong Kong: Oxford University Press.

Liaw, M. (2001). Exploring literary responses in an EFL classroom. Foreign Language Annals, 34(1), 35-44. https://doi.org/10.1111/j.1944-9720.2001.tb02800.x

Maley, A., \& Duff, A. (2005). Drama techniques: A resource book of communication activities for language teachers. Cambridge: Cambridge University Press. https://doi.org/10.1017/CBO9780511733079

Mart, C. T. (2012). Developing Speaking Skills through Reading. International Journal of English Linguistics, 2(6), 91-96. https://doi.org/10.5539/ijel.v2n6p91

Mart, C. T. (2013). The Grammar-Translation method and the use of translation to facilitate learning in ESL classes. Journal of Advances in English Language Teaching, 1(4), 103-105.

Mart, C. T. (2017). Literary texts: A means to promote language proficiency of upper-intermediate level EFL students. Journal of Education in Black Sea Region, 2(2), 44-55. https://doi.org/10.31578/jebs.v2i2.41

Mart, C. T. (2018a). The contentious debate over the language literature division. Journal of Language and Cultural education, 6(1), 117-127. https://doi.org/10.2478/jolace-2018-0008

Mart, C. T. (2018b). From communicative competence to language development. International Journal of English Linguistics, 892, 163-167. https://doi.org/10.5539/ijel.v8n2p163

Mart, C. T. (2018c). Literature in the language classroom: A recipe to maximize learning. L1 Educational Studies in Language and Literature, 18, 1-25. https://doi.org/10.17239/L1ESLL-2018.18.01.09

Mart, C. T. (2019). Reflections on discussions of literature: A language learning environment to promote speaking skills. The Journal of Social Sciences Research, 5(4), 846-850. https://doi.org/10.32861/jssr.54.846.850

McKay, S. (1982). Literature in the ESL classroom. TESOL Quarterly, 16(4), 529-536. https://doi.org/10.2307/3586470

Norton, B. (2011). The Practice of Theory in the Language Classroom. Issues in Applied Linguistics, 18(2), 110.

Paesani, K. (2011). Research in language-literature instruction: Meeting the call for change? Annual Review of Applied Linguistics, 31, 161-181. https://doi.org/10.1017/S0267190511000043

Park, G., \& Won, Y. (2003). The effect of English teaching through drama on communicative competence among primary school students. English Language Teaching, 15(2), 111-126.

Ur, P. (1996). A course in language teaching: Practice and theory. Cambridge: Cambridge University Press.

Via, R. (1972). English through drama. English Teaching Forum. Washington, D.C.: Information Center Service, United States Information Agency.

Whiteson, V. (1996). New ways of using drama and literature in language teaching. Alexandria, VA., TESOL. 
Zafeiriadou, N. (2009). Drama in language teaching: A challenge for creative development. Issues, 23, 4-9.

\section{Copyrights}

Copyright for this article is retained by the author, with first publication rights granted to the journal.

This is an open-access article distributed under the terms and conditions of the Creative Commons Attribution license (http://creativecommons.org/licenses/by/4.0/). 